
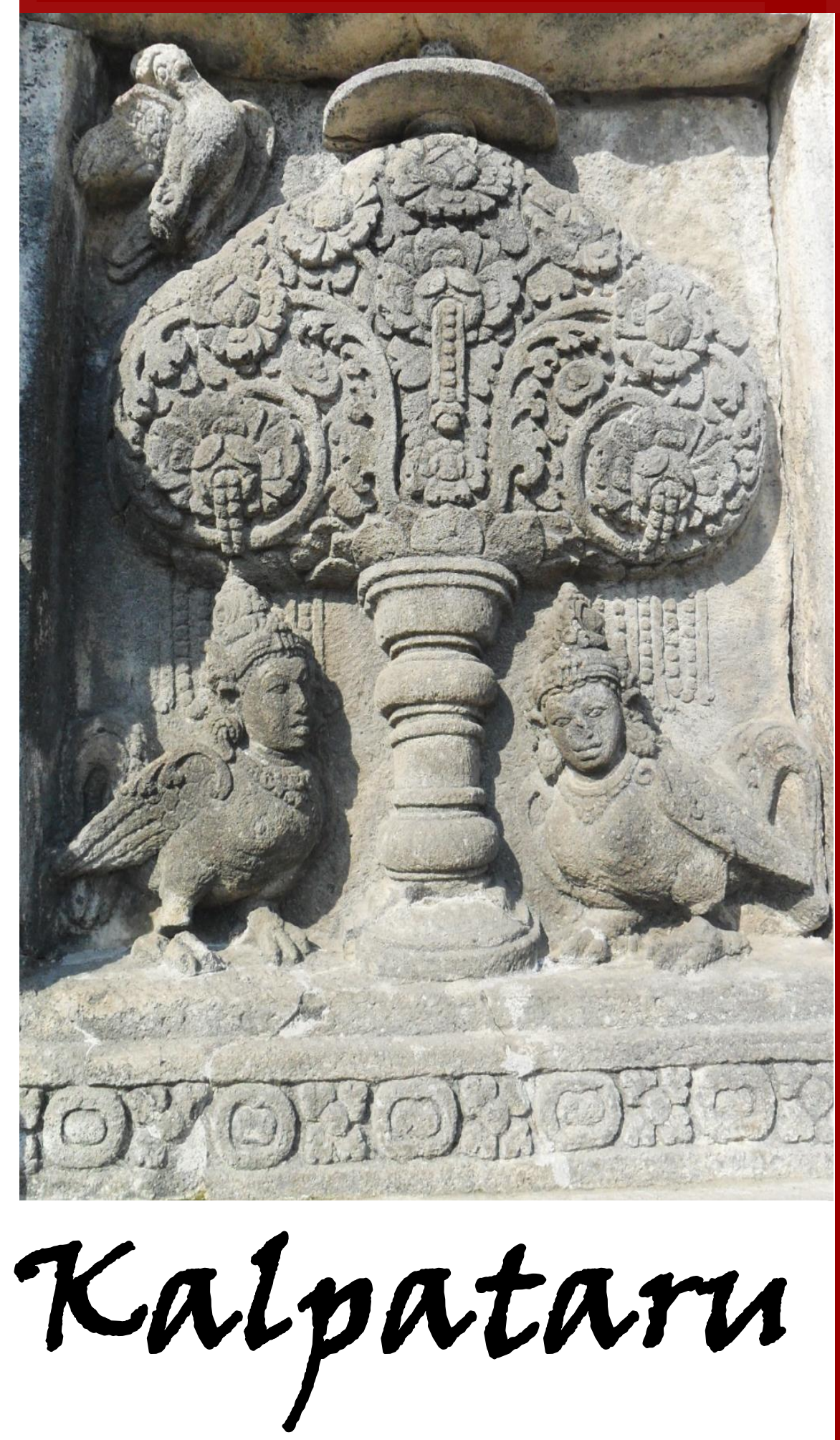

JURNAL SEJARAH DAN PEMBELAJARAN SEJARAH

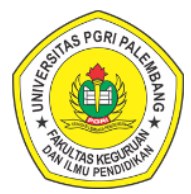

Program Studi Pendidikan Sejarah Jurusan Pendidikan IPS

Fakultas Keguruan dan IImu Pendidikan Universitas Persatuan Guru Republik Indonesia Palembang
Pengaruh Penerapan Model Project Based Learning Berbasis Video Vlog Dalam Proses Pembelajaran Sejarah Farena Adela, Nur Ahyani, Dina Sri Nindiati

Identifikasi Nilai Pedagogi Pada Pahatan Monolid Desa Jarakan Sebagai Sumber Pembelaran Sejarah Alzata Putra, Sukardi, Aan Suriadi

Nilai Sejarah Makam Puyang Ulak Laut di Pecah Pinggan Sebagai Sumber Pembelajaran Sejarah Berbasis Digital Dewi Cahya, Sukardi, Eva Dina Chairunisa

Pola Sebaran Permukiman di Kota Kayu Agung

I Made Lingga Wardana, Sukardi, Wandiyo

Peran Adam Malik Sebagai Ketua Sidang Majelis Umum PBB 1971 Rani Noviyanti

Pemanfaatan Foto dan Arsip Sebagai Sumber Pembelajaran Sejarah Riki Andi Saputro, Muhammad Fitri

Nilai-Nilai Sejarah Puyang Muara Rambang Sebagai Sumber Pelajaran Sejarah Lokal di SMA 01 Muarakuang Dwi Cahyati, Sukardi, Eva Dina Chairunisa

Pemikiran Abdul Mukti Ali Sebagai Sumber Pembelajaran Sejarah di SMA Patra Mandiri 1 Palembang Andika Merryanto Saputra, Aan Suriadi, Ahmad Zamhari

Perjuangan Hj. Rangkayo Rasuna Said Sebagai Pejuang Politik dan Pemikir Pergerakan Pada Masa Pra Kemerdekaan

Narani Agesti, Ageng Sanjaya

Nilai Sosial Religi Tradisi Manopeng Pada Masyarakat Banyiur Muhammad Fitri, Heri Susanto 
Kalpataru, Volume 7, Nomor 2, Desember 2021 (98-108)

\title{
NILAI SEJARAH MAKAM PUYANG ULAK LAUT DI PECAH PINGGAN SEBAGAI SUMBER PEMBELAJARAN SEJARAH BERBASIS DIGITAL
}

\author{
Dewi Cahya \\ Mahasiswa Progran Studi Pendidikan Sejarah, FKIP Universitas PGRI Palembang \\ Email: cahyadewy776@gmail.com \\ Sukardi \\ Dosen Progran Studi Pendidikan Sejarah, FKIP Universitas PGRI Palembang \\ Email: sukardipgri12@gmail.com \\ Eva Dina Chairunisa \\ Dosen Progran Studi Pendidikan Sejarah, FKIP Universitas PGRI Palembang \\ Email: eva.dinach_sj@univpgri-palembang.ac.id
}

\begin{abstract}
ABSTRAK
Makam Puyang Ulak Laut merupakan makam yang sangat penting dalam sejarah berdirinya Desa Pecah Pinggan, menurut warga setempat makam Puyang Ulak Laut ini sudah memeluk agama Islam, dapat dilihat dari makam yang sudah menghadap kearah kiblat sama halnya dengan makam yang ada di Desa Pecah Pinggan pada saat ini. Puyang Ulak Laut dijuluki oleh masyarakat sebagai pelindung desa dimana bisa dilihat dari perjuangannya dalam mempertahankan desa. Tujuan penelitian ini: untuk mengetahui nilai sejarah makam Puyang Ulak Laut di Pecah Pinggan yang dapat dijadikan sebagai sumber pembelajaran sejarah berbasis digital. Metode penelitian yang digunakan deskriptif kualitatif, dengan menggunakan cara pengumpulan sumber-sumber secara sistematis dan menggunakan sumber data. Teknik pengumpulan data menggunakan data lapangan seperti dokumentasi, observasi, dan wawancara, studi pustaka. Teknik analisis data dengan reduksi data, penyajian data, dan penarikan kesimpulan. Hasil penelitian ini adalah makam Puyang Ulak Laut merupakan makam yang sangat penting dalam sejarah berdirinya Desa Pecah Pinggan. Nilai sejarah yang dapat diambil dari makam Puyang Ulak Laut adalah tradisi ziarah makam dengan sistem sesajen. Dengan dijadikan sumber pembelajaran sejarah siswa dapat mengetahui sejarah lokal yang ada di sekitar sehingga menumbuhkan rasa ingin tahu yang tinggi terhadap siswa dan menimbulkan rasa cintanya terhadap desa.
\end{abstract}

Kata Kunci: Nilai Sejarah Makam Puyang Ulak Laut, Sebagai Sumber Pembelajaran Sejarah Berbasis Digital.

\section{A. PENDAHULUAN}

Wilayah Provinsi Sumatera Selatan memiliki luas $99.882,28 \mathrm{~km}$ dan terletak antara 1-4 Lintang Selatan dan 102-108 Bujur Timur. Meliputi areal seluas 99.598,689 $\mathrm{km}$ atau $995.986,89$, luas wilayah Indonesia, dan batasbatas wilayah Utara berbatasan dengan Provinsi Jambi, Timur berbatasan dengan Provinsi Bangka Belitung, Selatan berbatasan dengan Provinsi Lampung, Barat berbatasan dengan Provinsi Bengkulu (Laksana, 2013:23).

Provinsi Sumatera Selatan merupakan salah satu bagian integral dari Republik Indonesia yang sebagian besar wilayah terletak di pulau Sumatera. Sumatera Selatan sejak berabad yang lalu dikenal juga dengan sebutan Bumi Sriwijaya, pada abad ke-7 Masehi wilayah ini merupakan pusat Kerajaan Sriwijaya yang juga terkenal dengan kerajaan maritim terbesar dan terkuat di Nusantara. Sejak abad ke-13 sampai abad ke-14, wilayah ini berada di bawah kekuasaan Majapahit. Ketika masih berjaya, Kerajaan Sriwijaya juga menjadikan Palembang sebagai kota kerajaan (Laksana, 2013).

Kabupaten Ogan Komering Ulu Selatan (OKU Selatan) adalah salah satu kabupaten di Provinsi Sumatera Selatan, yang terbentuk pada tahun 2004 memiliki wilayah administrasi 
terdiri atas 19 kecamatan, yaitu kecamatan Runjung Agung, Banding Agung, Buay Pemaca, Buay Rawan, Buay Runjung, Buay Sandang Aji, Kisam Tinggi, Mekakau llir, Muaradua (Ibukota), Muaradua Kisam, Pulau Beringing, Simpang, Warkuk Ranau Selatan, Buana Pemaca, Tiga Dihaji, Sidang Danau, Buay Pematang Ribu Ranau Tengah, Sungai Are, Kisam llir (Badan Pusat Statistik, 2018:9). Dari penjelasan di atas dapat disimpulkan bahwa Sumatera Selatan ini mempunyai banyak keanekaragaman suku yang berbeda sehingga menjadikan Sumatera Selatan menjadi kaya akan kebudayaan.

Beragamnya kebudayaan dan kepercayaan masyarakat tidak lepas dari sejarah bangsa Indonesia yang mempunyai letak geografis yang sangat strategis. Oleh sebab itu, bangsa Indonesia bukan hanya dari berbagai suku tetapi juga dari berbagai jenis kebudayaan. Salah satu wilayah yang memiliki sumber daya alam dan sumber daya manusia yang berlimpah adalah Kabupaten OKU Selatan yang mata pencaharian penduduknya sebagian besar bertani tanaman perkebunan kopi sejak 1975 dan sekarang berubah menjadi bercocok tanam (Ni Made, 2020).

Budaya merupakan komponen pokok dari kebudayan yang bersifat abstrak dan terdiri dari pikiran-pikiran, gagasan, konsep, serta keyakinan. Dengan demikian sistem kebudayaan merupakan bagian dari kebudayaan yang dalam bahasa Indonesia lebih lazim disebut sebagai adat istiadat. Dalam adat istiadat terdapat juga sistem norma dan disitulah salah satu fungsi sistem budaya adalah menata serta menetapkan tindakan-tindakan dan tingkahlaku manusia (Laksana, 2013:8).

Kebudayaan Provinsi Sumatera Selatan sebagian besar terpengaruh oleh budaya Melayu. Selain itu juga ada beberapa kebudayaan yang terpengaruh oleh Islam, dan ada pula yang dipengaruhi oleh kebesaran dari Kerajaan Sriwijaya. Sumatera Selatan juga mempunyai ragam etnik, ciri kebudayaan dan segi bahasanya (Alimin, 2018).

Desa Pecah Pinggan terletak di Kecamatan Sungai Are Kabupaten Ogan Komering Ulu Selatan. Pada zaman itu Desa Pecah Pinggan masih dijajah oleh Belanda pada waktu 300 tahun yang lalu, masyarakat Desa
Pecah Pinggan ini mayoritas memeluk agama Islam dan bersuku Semendo. Asal mula Desa Pecah Pinggan ini berasal dari sebuah pohon yang berada di samping desa, pohon tersebut bernama pecah pinggan pohon ini juga mempunyai getah yang begitu banyak sehingga masyarakat setempat memanfaatkannya menjadi sebuah piring atau sering disebut pinggan lengkiyu, pinggan/piring ini menjadi simbol bagi masyarakat desa dimana pinggan ini mudah sekali pecah sehingga jika masyarakat pecah pinggan tentram dan damai maka piring/pinggan ini akan selalu terjaga dan tidak akan pecah begitu juga sebaliknya jika Desa Pecah Pinggan tidak tentram maka akan pecahlah pinggan tersebut, sehengga leluhur desa ini memberi nama desa dengan sebutan Desa Pecah Pinggan (Wawancara Jlimin, 61 tahun, 21 Mei 2021, pukul 11:25 WIB).

Puyang Ulak Laut adalah seorang pelayar dari Laut Tengah, dan tinggal bersama anak-anak dan istri, nama asli Puyang Ulak Laut ini adalah Puyang Kandang karena kesaktiannya dalam membantu Puyang Kaur menghentikan ombak besar maka Puyang Kaur mengganti nama Puyang Kandang menjadi Puyang Ulak laut, dengan kejadian itu nama Puyang Kandang di rubah menjadi Puyang Ulak Laut. Puyang Ulak Laut juga termasuk orang yang dianggap penting bagi Desa Pecah Pinggan karena dianggap mampu melindungi desa (Wawancara Jlimin, 61 tahun, 21 Mei 2021, pukul 11:25 WIB).

Nilai sejarah yang dapat diambil dari makam Puyang Ulak Laut adalah tradisi ziarah yang masih menggunakan sistem sesajen yang dibawa oleh warga Desa Pecah Pinggan sebagai penghormatan kepada Puyang Ulak Laut, yang dianggap sebagai pelindung desa. Berdasarkan latar belakang masalah di atas maka peneliti tertarik untuk melakukan penelitian dengan judul "Nilai Sejarah Makam Puyang Ulak Laut di Desa Pecah Pinggan sebagai Sumber Pembelajaran Digital di SMA Shailendra Palembang".

\section{B. METODE PENELITIAN}

Deskriptif kualitatif, yang menggunakan cara mengumpulkan sumber-sumber secara sistematis dan menggunakan sumber data 
secara mendalam. Penelitian deskriptif kualitatif diuraikan dengan kata-kata menurut responden, apa adanya sesuai dengan pertanyaan penelitiannya, kemudian dianalisis dengan katakata apa yang melatarbelakangi responden berperilaku (berpikir, berperasaan, dan bertindak) seperti itu tidak seperti lainnya, direduksi, ditriangulasi, disimpulkan (diberi makna oleh peneliti), dan diverifikasi (dikonsultasikan kembali kepada responden dan teman sejawat). Minimal ada tiga hal yang digambarkan dalam penelitian kualitatif, yaitu karakteristik pelaku, kegiatan, atau kejadiankejadian yang terjadi selama penelitian, dan keadaan lingkungan atau karakteristik tempat penelitian berlangsung (Sugiyono, 2017:205).

\section{Data dan Sumber Data}

Jenis data pada penelitian ini adalah data. Sumber data primer atau data tangan pertama yaitu data yang diperoleh langsung dari subjek penelitian dengan menggunakan alat pengukur atau alat pengamblian data langsung pada subjek sebagai sumber informasi yang dicari dan sumber data sekunder atau data tangan kedua adalah data yang diperoleh lewat pihak lain, dan tidak langsung diperoleh oleh peneliti dari subjek penelitiannya (Azwar, 2016:91).

Data sekunder yaitu data yang telah dikumpulkan untuk maksud selain menyelesaikan masalah yang sedang dihadapi. Data ini dapat ditemukan dengan cepat. Dalam penelitian ini yang menjadi sumber data sekunder adalah literatur, artikel, jurnal serta situs di internet yang berkenaan dengan penelitian yang dilakukan.

\section{Teknik Pengumpulan Data}

Teknik pengumpulan data merupakan langkah yang paling strategis dalam penelitian, tujuan utama dari penelitian adalah mendapatkan data. Pengumpulan data dapat dilakukan dalam berbagai setting, berbagai sumber, dan berbagai cara, dilihat dari setting berbagai sumber, dan berbagai cara. Bila dilihat dari settingnya data dapat dikumpulkan pada setting alami (natural setting). Bila dilihat dari sumber datanya, maka pengumpulan data dapat menggunakan sumber primer dan sekunder. Sumber primer adalah sumber data yang langsung memberikan data pada pengumpul data, dan sumber sekunder merupakan sumber yang tidak langsung memberikan data pada pengumpul data (Sugiyono, 2018).

\section{Teknik Analisis data}

Menurut Sugiyono (2014:89) analisis data kualitatif adalah bersifat induktif suatu analisis berdasarkan data yang diperoleh, selanjutnya dikembangkan lagi secara berulang-ulang selanjutnya dapat disimpulkan berdasarkan data yang terkumpul tersebut, peneliti melakukan tiga kegiatan analisis data yaitu reduksi data, penyajian data dan kesimpulan.

\section{HASIL DAN PEMBAHASAN Hasil Penelitian}

Teknologi informasi saat ini sangat berpengaruh dalam diri seseorang dalam belajar, untuk lebih muda mendapatkan informasi dan lain sebagainya, teknologi juga menyediakan peluang bagi pendidik untuk mengembangkan teknik pembelajaran sehingga menghasilkan hasil yang maksimal. Demikian juga bagi peserta didik, dengan multimedia diharapkan mereka akan lebih mudah untuk menentukan dengan apa dan bagaimana dapat menyerap informasi secara cepat dan efisien. Oleh karena itu, kehadiran multimedia dalam proses belajar menjadi sangat bermanfaat (Sugianto, 2013).

Salah satu media pembelajaran yang diharapkan dapat menciptakan suasana belajar yang menarik dan kondusif yaitu dengan penggunaan multimedia Flipbook. Dengan menggunakan media pembelajaran tersebut diharapkan dapat memberikan pembaharuan dalam proses pembelajaran di kelas. Penggunaan media Flash Flipbook dapat menambah motivasi belajar peserta didik dan juga dapat mempengaruhi prestasi atau hasil belajar peserta didik. Penggunaan Flipbook juga dapat meningkatkan pemahaman dan meningkatkan pencapaian hasil belajar (Sugianto, 2013).

Perkembangan teknologi e-book mendorong terjadinya perpaduan antara teknologi cetak dengan teknologi komputer 
dalam kegiaan pembelajaran, salah satunya yaitu modul. Modul dapat ditransformasikan penyajiannya ke dalam bentuk elektronik sehingga diberi istilah modul elektronik atau modul virtual. Modul elektronik adalah sebuah bentuk penyajian bahan belajar mandiri yang disusun secara sistematis ke dalam unit pembelajaran terkecil untuk mencapai tujuan pembelajaran tertentu yang disajikan ke dalam format elektronik yang di dalamnya terdapat animasi, audio, navigasi yang membuat pengguna lebih interaktif dengan program. Dengan adanya modul elektronik yang bersifat interaktif ini proses pembelajaran akan melibatkan tampilan audio visual, sound, movie dan yang lainnya serta program tersebut pemakaiannya mudah dipahami sehingga dapat dijadikan media pembelajaran yang baik.

Pembuatan media pembelajaran berbasis multimedia dilakukan dengan menggunakan perangkat lunak/software yang bersifat open source. Perangkat lunak tersebut adalah Kvisoft Flipbook Marker yang merupakan perangkat lunak/software yang digunakan untuk membuat tampilan buku atau bahan ajar lainnya menjadi sebuah buku elektronik digital berbentuk flipbook. Perangkat lunak tersebut dapat diunduh secara bebas atau gratis melalui akses internet (Sugianto, 2013). Kvisoft Flipbook Maker adalah perangkat lunak yang handal yang dirancang untuk mengkonversi file PDF ke halaman-balik publikasi digital. Software ini dapat mengubah tampilan file PDF menjadi lebih menarik seperti layaknya sebuah buku. Tidak hanya itu, Kvisoft Flipbook Maker juga dapat membuat file PDF menjadi seperti sebuah majalah, Majalah Digital, Flipbook, Katalog Perusahaan, Katalog digital dan lain-lain. Dengan menggunakan perangkat lunak tersebut, tampilan media akan lebih variatif, tidak hanya teks, gambar, video, dan audio juga bisa disisipkan dalam media ini sehingga proses pembelajaran akan lebih menarik.

Pada Kvisoft Flipbook Maker kita dapat menambahkan file-file gambar, pdf, swf, dan file video berformat FLV dan MP4. Sedangkan keluaran atau output dari software ini dapat berupa HTML, EXE, ZIP, dan APP. Output TI Flash membalik buku sebagai format HTML yang memungkinkan kalian untuk mengupload ke website untuk dilihat secara online. Output sebagai berdiri sendiri EXE untuk pengiriman CD. Paket itu sebagai format ZIP untuk email cepat. Dan output berupa APP dapat digunakan di I-Phone, Tablet, I-Pad, dan lain-lain.

\section{Tahapan Produksi Perencanaan dalam Persiapan Pembuatan Flip Book.}

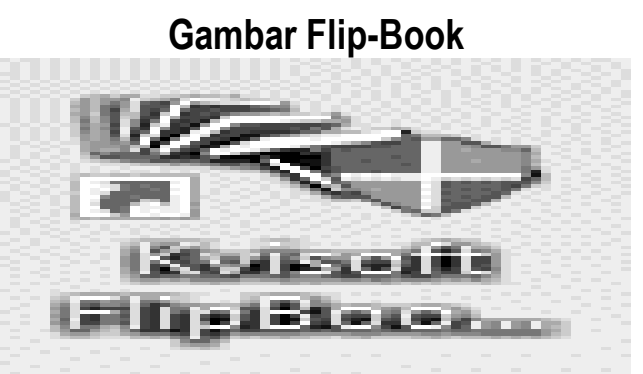

1. Menelaah tujuan pemebelajaran. Hal ini menjadi acuan dari penyusunan isi dari flip book tersebut.

2. Menyusun jabaran materi untuk dijadikan sebagai isi dari flip book.

3. Materi yang telah dijabarkan, disusun menjadi rangkuman yang mewakili dari indikator pembelajaran dari materi tersebut.

4. Mempersiapkan alat dan bahan yang akan digunakan untuk pembuatan fisik flip book, seperti kertas A4 (boleh menggunakan berbagai jenis kertas) serta bahan lainnya untuk hiasan flip book, gunting dan lainlain.

\section{Langkah-langkah Pembuatan Flip Book}

Pembuatan flip book bisa manual atau dibuat secara hand made, atau bisa dengan bantuan aplikasi komputer, word, canva, misalnya aplikasi Ms. Powerpoint, dan lain-lain (Wahyuni, 2016:24).

1. Membukak Aplikasi flip book

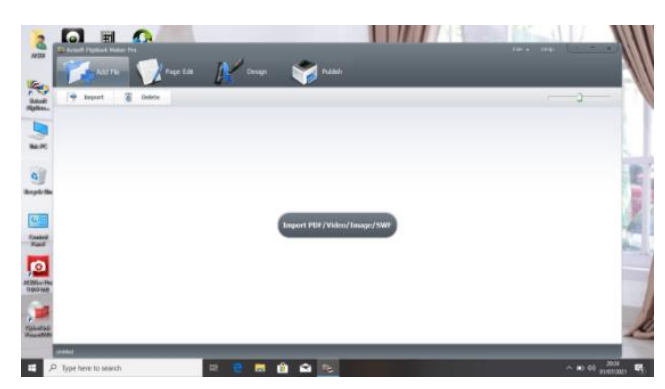


2. Mengekspor materi yang sudah dijadikan file pdf ke flip book.

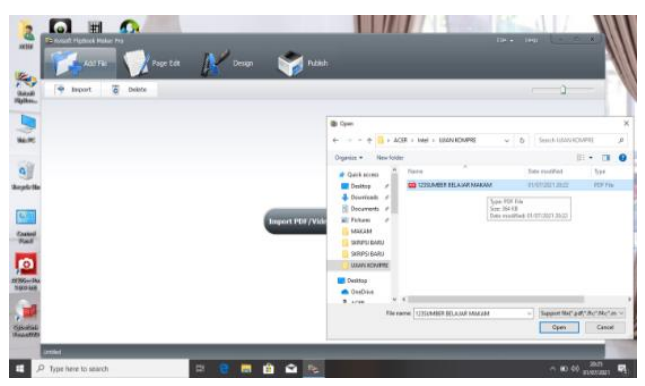

3. Setelah memasukkan file ke pdf maka akan menunggu beberapa detik agar bisa muncul materi yang akan dibuat.

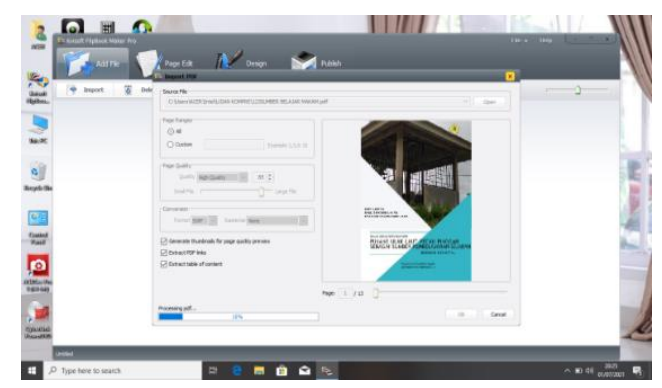

4. Setelah menunggu beberapa menit akan muncul materi belajar yang telah dirangkum pada tahap pra produksi.

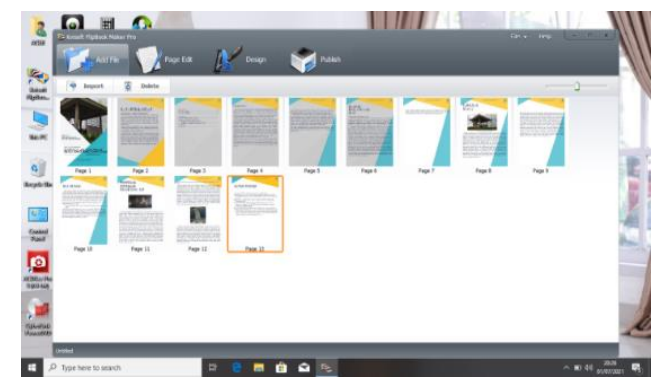

5. Mengatur ukuran kertas yang akan dijadikan flip book. Adapun ukuran yang dipakai biasanya kertas A4.

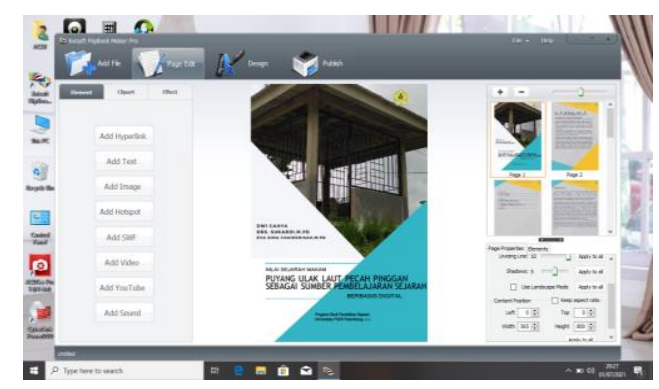

6. Membubuhkan hiasan-hiasan maupun gambar sesuai kebutuhan.

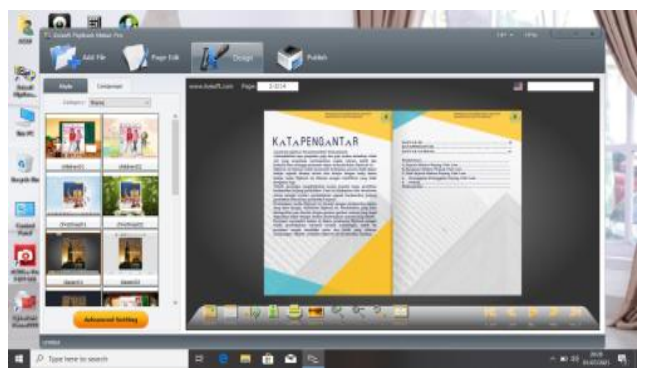

7. Tahap akhir yaitu mempublik materi yang sudah dibuat dan bisa memilih bentuk publik sesuai yang diinginkan seperti, HTML, EXE, ZIP, APP, SCREENSAVER.

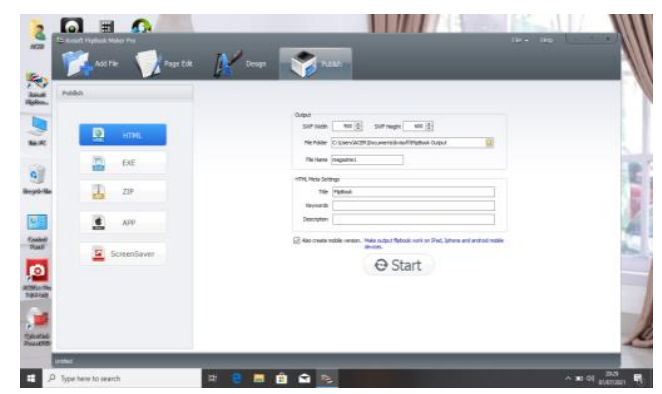

8. Setelah memilih publik akan muncul forum email dan pasword untuk link.

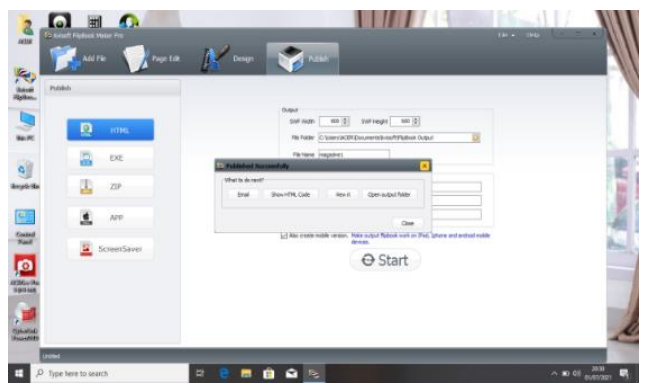

9. Setelah beberapa menit maka akan muncul link.

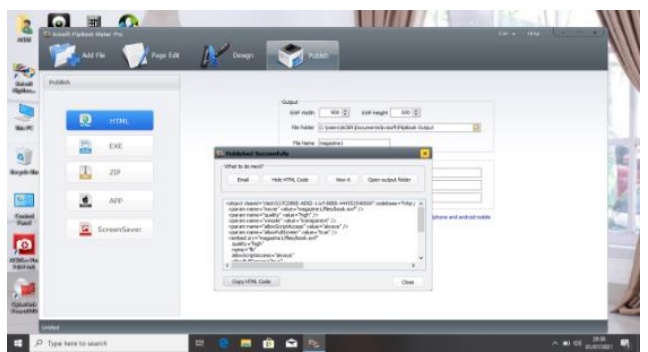


10. Maka jadilah media pembelajaran berbasis flip book yang diinginkan.

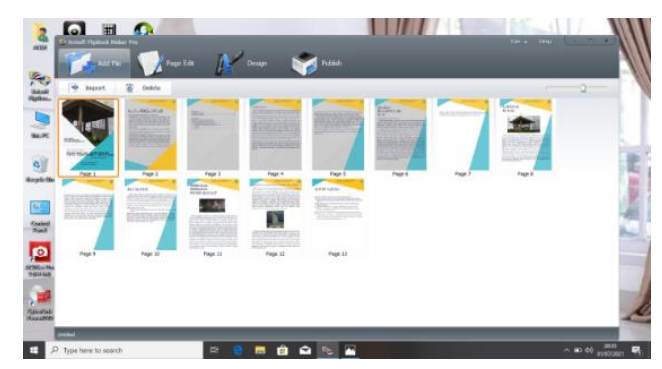

Tahap Akhir dari Pembuatan Media

Tahap ini merupakan sentuhan akhir sebelum dimanfaatkan. Adapun tahap pasca prosuksi antara lain meliputi:

1. Editing. Hal ini dilakukan untuk mengecek kembali isi maupun desain flip book.

2. Revisi kekurangan yang ada dalam isi maupun desain flip book sehingga sesuai dengan perencanaan yang telah dibuat.

3. Flip book sudah bisa untuk digunakan sebagai media pembelajaran. Flip book ini bisa digunakan secara individu maupun kelompok. Seperti halnya media pembelajaran lainnya, flip book mempunyai keistimewaan tersendiri. Adapun keistimewaan dari flip book antara lain, dengan menggunakan media pembelajaran flip book, siswa diajak untuk mengembangkan kreatifitasnya. Hal ini karena dalam pembuatan flip book baik itu flip book yang sudah ada maupun buatan tangan siswa, biasanya dibubuhkan gambar-gambar atau hiasan lainnya sesuai keinginan siswa, sehingga rangkuman yang terdapat dalam flip book menarik untuk dibaca (Wahyuni, 2016:24).

\section{Pembahasan}

\section{Asal Usul Puyang Ulak Laut}

Puyang Ulak Laut ini berasal dari Semende Dahat Desa Romantai dahulunya Puyang Ulak Laut ini sudah mengikuti perang melawan Belanda, pada saat pertarungan melawan Belanda Puyang Ulak Laut ini nyusuk ke Desa Pecah Pinggan beserta anak istri beserta keluarganya sejak itulah Puyang Ulak Laut ini mengadakan pembukaan pertama di Desa Pecah Pinggan.
Puyang Ulak Laut adalah seorang pelayar laut tengah yang memiliki nama asli Kandang, Puyang Kandang ini mempunyai 3 anak yang bernama (1. Jagoani, 2. Rajawani, 3 . Girinong) dan mempunyai istri bernama Mataram selama hidupnya Puyang Ulak Laut ini hidup seperti masyarakat lainnya, pada saat itu Puyang Kendang ini diundang oleh Puyang Kaur untuk mengadu kesaktian di Bengkulu tempatnya di Pulau Tengah pada saat Puyang Kendang berada di Pulau Tengah Puyang Kendang ini disambut dengan baik dan diberikan jamuan makanan yang begitu banyak oleh orang Bengkulu tanpa disadari oleh Puyang Kendang bahwa makanan tersebut sudah diberi racun oleh orang Bengkulu Puyang Kendang pun tidak menyadari bahwa makanan tersebut sudah dikasih racun dan dimakan dengan lahap oleh Puyang Kendang melihat kejadian itu prajurit Bengkulu pun heran melihat kejadian itu karena makanan yang diberi racun tersebut tidak memberikan efek sedikitpun bagi Puyang Kendang, pada saat Puyang Kaur ingin kembali lagi ke Desa Pecah Pinggan Puyang Kaur mendengar akan ada kejadian tsunami yang besar besaran dan akan ada ombak yang akan menerjang pulau tengah sehingga Puyang Kaur meminta bantuan kepada Puyang Kendang bagaimana caranya untuk menghindari ombak di Pulau Tengah karena kesaktian Puyang Ulak Laut ini sehingga tidak terjadi tsunami dan ombak besar itu terjadi, dengan adanya kejadian tersebut Puyang Kaur mengubah nama Puyang Kendang menjadi Puyang Ulak Laut dengan kesaktiannya maka Puyang Ulak Laut sebagai Hulubalang desa karena dianggap mampu melindungi desa.

\section{Nilai Sejarah Makam Puyang Ulak Laut}

Nilai adalah rujukan dan keyakinan dalam menentukan pilihan. Nilai merupakan sesuatu yang diinginkan sehingga melahirkan tindakan pada diri seseorang (Mulyana, 2014:84). Nilai pada dasarnya dalam sebuah kehidupan terdapat nilai-nilai tertentu yang harus dianut oleh semua anggota. Nilai-nilai tersebut dimiliki dan dikembangkan oleh seseorang. Nilai tersebut akan menjadi pegangan dan sekaligus pedoman bagi seseorang dalam berfikir dan bertindak, salah satu nilai yang ada dalam 
masyarakat adalah nilai sejarah yang sebenarnya telah ada bersamaan dengan keberadaan masyarakat itu sendiri (Djono, 2017:78).

Nilai sejarah yang diambil dari makam Puyang Ulak Laut adalah tradisi ziarah makam yang masih menggunakan sesajen, yang sering dilakukan oleh warga Desa Pecah Pinggan sebagai penghormatan kepada Puyang Ulak Laut sebagai pelindung Desa Pecah Pinggan. Dan berdoa bersama memohon ampunan tuhan agar Puyang Ulak Laut dan puyang-puyang lainnya diampuni segala dosa dan kesalahannya, diterima segala amal dan ibadahnya dan mendapat tempat di alam kubur sebagai tempat raudah fil jannah.

\section{Bangunan Makam Puyang Ulak Laut}

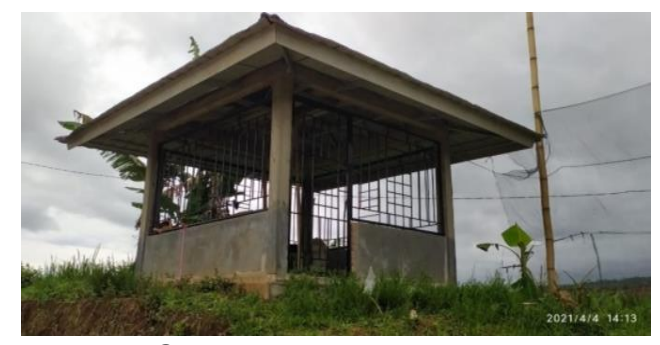

Gambar Koleksi: Pribadi

Makam Puyang Ulak Laut yang memiliki sejarah penting bagi berdirinya Desa Pecah Pinggan karena dilihat dari perjuangan Puyang Ulak Laut beserta anak dan cucunyalah sehingga terbentuk salah satu desa yang disebut Pecah Pinggan ini, makam Puyang Ulak Laut ini terletak di pertengahan Desa Tanah Makam yang sedikit menggunung atau sedikit membukit di atas sanalah makam Puyang Ulak Laut ditempatkan tingginya sekitar $100 \mathrm{~cm}$, makam ini tidak jauh beda dengan makam yang ada pada saat ini adapun panjang tanah makam $3,25 \mathrm{~cm}$, dan lebar 2 meter nisan yang ada pada makam berasal dari batu, nisan mempunyai ukuran tinggi $50 \mathrm{~cm}$, lebar batu nisan $30 \mathrm{~cm}$, diperkirakan makam ini telah ada pada berabat tahun yang lalu. Jika dilihat sekarang bangunan makam ini sudah jauh berbeda dengan bangunan yang sebelumnya bangunan makam pada saat ini sudah direnovasi dan layak untuk dikunjungi dimana makam ini sudah dibangun menggunakan semen. Adapun keunikan dari makam ini adalah dimana batu nisan biasanya menggunakan semen atau kayu sedangkan makam Puyang Ulak Laut ini menggunakan batu besar yang dijadikan batu nisan.

Keberadaan makam ini juga bisa dijadikan sebagai sumber belajar bagi pelajar sebagai generasi penerus bangsa. Selain itu juga kunjungan ke makam leluhur/puyang menjadi suatu media pembelajaran. Kunjungan atau ziarah makam bertujuan untuk mengetahui asal-usul keturunan nenek moyang suatu suku bangsa serta sebagai penghormatan kepada nenek moyang Ulak Laut untuk mengingatkan kembali tentang sejarah makam Puyang Ulak Laut sebagai pelindung desa, dari sebuah kebiasaan tradisi ziarah makam yang dilakukan oleh masyarakat menjadi suatu materi tentang percampuran dinamisme dengan agama Islam. Dimana kepercayaan animisme merupakan kepercayaan yang dianut oleh nenek moyang dahulunya. Namun pada kenyataannya kepercayaan itu masih dipakai oleh masyarakat yang sudah menganut agama Islam. Hal itu yang dapat menjadi pembahasan dalam pembelajaran siswa-siswa sekolah menengah awal. Sehingga dapat menjadi sumber belajar dan sebuah tradisi yang dapat dipelajari melalui materi kepercayaan nenek moyang.

\section{Tradisi Ziarah Makam}

Dalam tradisi ziarah ini yaitu kunjungan terhadap makam disebut ziarah, terutama dilakukan terhadap leluhur, orang tua, atau anggota keluarga yang dicintai. Maksud dari ziarah ini untuk memberikan doa-doa kepada nenek moyang sekaligus membawa sesajen yang sering dilakukan oleh masyarakat apabila ingin berziarah, setiap orang yang ingin berziarah ke makam Puyang Ulak Laut bukan hanya saat hari-hari besar saja melainkan pada hari-hari biasapun masih ada masyarakat yang berkunjung untuk memberikan doa kepada Puyang Ulak Laut. Maksud ziarah ini ialah untuk mengenang kebesaran tuhan. Dan menyampaikan doa agar arwah ahlul kubur diterima segala amal dan perbuatannya dan diterima di surga Allah. Ziarah adalah perbuatan sunnah, artinya: jika dilakukan mendapat pahala dan kalau tidak dilakukan tidak berdosa (Suhadi, 1994:27). 
Banyak pengunjung yang datang kemakam ini pada hari besar Islam dengan membawa sesajen pada hari-hari biasa pun masih ada masyarakat yang berkunjung/ziarah, dan berdoa bersama dengan ilmu tasawuf (kebatinan) dan memberikan doa agar makam Puyang Ulak Laut ini diampuni segala dosadosanya dan diterima di sisi surganya Allah. Untuk pengunjung yang berziarah bermacammacam baik dari desa itu sendiri maupun pengunjung dari luar, masyarakat yang datang biasanya hanya memberikan doa (Wawancara Jlimin, 61 tahun, 21 Mei 2021, pukul 11:25 WIB).

Keberadaan makam ini juga bisa dijadikan sebagai sumber belajar bagi pelajar sebagai generasi penerus bangsa. Selain itu juga kunjungan ke makam leluhur/puyang menjadi suatu media pembelajaran. Kunjungan atau ziarah makam bertujuan untuk mengetahui asal-usul keturunan nenek moyang suatu suku bangsa serta sebagai penghormatan kepada nenek moyang Ulak Laut untuk mengingatkan kembali tentang sejarah makam Puyang Ulak Laut sebagai pelindung desa sampai saat ini makam ini masih dikunjungi oleh kalangan masyarakat, dari sebuah kebiasaan tradisi ziarah makam yang dilakukan oleh masyarakat menjadi suatu materi tentang percampuran dinamisme dengan agama Islam. Di mana kepercayaan animise merupakan kepercayaan yang dianut oleh nenek moyang dahulunya. Namun pada kenyataannya kepercayaan itu masih dipakai oleh masyarakat yang sudah menganut agama Islam. Hal itu yang dapat menjadi pembahasan dalam pembelajaran siswa-siswi sekolah menengah awal. Sehingga dapat menjadi sumber belajar dan sebuah tradisi yang dapat dipelajari melalui materi kepercayaan nenek moyang.

\section{Peninggalan-peninggalan Puyang Ulak Laut}

Benda peninggalan Puyang Ulak Laut yang digunakan selama ia hidup, yaitu:

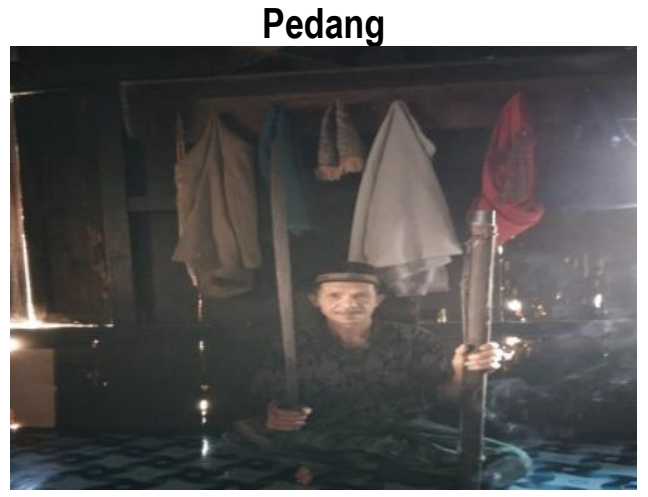

Gambar Koleksi Pribadi

Benda pusaka peninggalan Puyang Ulak Laut selama hidupnya yaitu sebuah pedang. Pedang ini memiliki panjang $50 \mathrm{~cm}$. Pedang ini pada zaman dahulu menurut sumber merupakan alat untuk peperangan sekaligus jimat penolakbalak yang digunakan Puyang Ulak Laut selama hidupnya, pedang ini masih dijaga atau disimpan oleh guru kunci makam Puyang Ulak Laut yang merupakan masih salah satu keturunan dari Puyang Ulak Laut pedang ini dijaga dan dirawat, pada dasarnya pedang ini dikeluarkan setelah dua bulan sekali pada saat membuka pedang ini terlebih dahulu membaca doa-doa yang dilakukan oleh pemegang pedang setelah dibuka pedang tersebut dibersihkan dengan hindup kecil beserta ramuan-ramuan (Wawancara Jlimin, 61 tahun, 21 Mei 2021, pukul 11:25 WIB).

\section{Kegunaan Pedang yang Digunakan Oleh Puyang Ulak Laut Selama Hidupnya}

Kegunaan pedang yang digunakan oleh Puyang Ulak Laut selama hidupnya adalah untuk dijadikan sebagai alat perang dalam penjajahan melawan Belanda selain dari alat perang pedang ini juga dijadikan sebagai jimat atau alat pelindung agar Puyang Ulak Laut terhindar dari mara bahaya. Setelah Puyang Ulak Laut ini meninggal pedang ini diwariskan kepada salah satu yang masih keturunan dari Puyang Ulak Laut, sampai saat ini pedang masih dijaga dengan baik oleh salah satu guru kunci atau pemangku adat Desa Pecah Pinggan. 


\section{Nilai Sejarah Makam Puyang Ulak Laut di Desa Pecah Pinggan Sebagai Sumber Pembelajaran Sejarah Berbasis Digital di SMA Shailendra Palembang}

Makam Puyang Ulak Laut merupakan makam yang sangat penting dalam sejarah berdirinya Desa Pecah Pinggan. Menurut warga setempat makam Puyang Ulak Laut ini sudah memeluk agama Islam, dapat dilihat dari makam Puyang Ulak Laut yang sudah menghadap kearah kiblat, sama halnya dengan makammakam lainnya yang berada di Desa Pecah Pinggan pada saat ini, sistem penguburan yang masih sama pada masa sekarang. Dalam agama Islam kegiatan pemakaman mayat merupakan tahap terakhir dari rangkaian kegiatan menangani orang yang telah meninggal. Kegiatan pemakaman mayat dilakukan dengan cara memandikan, mengkhafani dan mensholatkan hukumnya fardhu kifayah. Proses pemakaman diawali dengan menggali atau mempersiapkan liang lahat, dan menempatkan mayat di dalamnya, kemudian diazankan terlebih dahulu kemudian menimbunnya dengan tanah dan berakhir dengan memberikan tanda/nisan dari batu atau kayu di atas kubur.

Makam yang berada pada Desa Pecah Pinggan merupakan makam asli dari pemerintah Desa Pecah Pinggan dahulu makam Puyang Ulak Laut ini juga terpisah dari makam-makam lainnya makam ini terkhusus di pertengahan desa, tanah makam ini juga memiliki sejarah bagi Desa Pecah Pinggan dengan bentuk menggunung atau seperti bukit. Nisan yang ada pada makam berupa nisan yang terbuat dari batu. Diperkirakan makam ini telah ada pada berabat tahun yang lalu, makam Puyang Ulak Laut yang duhulunya hanya dibatasi dengan batu kini telah diperbaiki dengan memasang keramik/semen disekitar area pemakaman, ini dilakukan dengan alasan agar setiap warga yang melakukan ziarah agar lebih nyaman dan mempunyai tempat untuk dapat berdoa dengan nyaman.

Materi tentang makam Puyang Ulak Laut dapat dijadikan sebagai materi sumber pembelajaran sejarah di kelas XI SMA Shailendra Palembang pada Standar Kompetensi: 5. Memahami perkembangan masyarakat sejak masa Hindu-Budha sampai masa kolonial Eropa. Kompetensi Dasar: 5.2. mendeskripsikan perkembangan masyarakat, kebudayaan dan pemerintahan pada masa Islam di Indonesia serta peninggalanpeninggalannya. Materi pembelajaran: contoh peninggalan-peninggalan sejarah bercorak Islam diberbagai daerah. Hal ini karena makam Puyang Ulak Laut memiliki nilai sejarah yang dapat diketahui dari cerita rakyat dan dokumen tentang makam Puyang Ulak Laut.

\section{Pemahaman Guru Mata Pelajaran Sejarah Tentang Pemanfaatan Nilai Sejarah Makam Puyang Ulak Laut di Desa Pecah Pinggan}

Menurut ibu Merista Salako, S.Pd. dalam memahami pembelajaran, seorang guru sejarah harus lebih memahami lebih dalam mempelajari materi yang akan diajarkan, selain itu juga seorang guru sejarah harus memperbanyak membaca agar dapat menambah wawasan dalam proses belajar mengajar, karena dalam pelajaran sejarah anak-anak mengetahui bahwa belajar sejarah hanya mencatat dan dan menghapal saja oleh karena itu guru sejarah harus kreatif agar siswa tidak jenu atau bosan dalam belajar dalam pelaksanaan pembelajaran di SMA Shailendra Palembang sesuai dengan kurikulum yang ada atau yang telah ditentukan.

Menurut ibu Merista Salako, S.Pd. memahami materi yang akan dipelajari khususnya materi tentang makam Puyang Ulak Laut, seorang guru sejarah harus mengetahui lebih banyak tentang makam puyang ulak laut atau membaca dari dokumen-dokumen tentang makam Puyang Ulak Laut dan banyak bertanya kepada masyarakat yang lebih mengetahui mengenai keberadaan makam tersebut khususnya makam Puyang Ulak Laut.

Menurut ibu Merista Salako, S.Pd. untuk melakukan sumber pembelajaran sejarah lokal berbasis digital khususnya tentang makam Puyang Ulak Laut harus ada kriteria pemilihan materi pembelajaran sejarah berbasis digital adalah harus mengacu pada standar kompetensi dan kompetensi dasar, yang ditentukan oleh kurikulum yang ada, setelah itu materi pembelajaran dapat dikembangkan dalam kegiatan pembelajaran. Materi tentang makam Puyang Ulak Laut termasuk pada 
standar kompetensi (1) memahami perkembangan masyarakat sejak, masa HinduBudha masa Kolonial Eropa.

Dari wawancara penelitian dengan ibu Merista Salako, S.Pd. sebagai guru sejarah di kelas XI SMA Shailendra Palembang dapat diketahui bahwa guru sejarah khususnya guru sejarah SMA Shailendra Palembang sudah memahami mengenai nilai sejarah makam Puyang Ulak Laut dan dapat menempatkan materi tentang makam Puyang Ulak Laut sebagai materi sumber pembelajaran sejarah berbasis digital di SMA Shailendra Palembang serta dapat dikembangkan dalam proses pembelajaran sejarah berbasis digital karena dalam keadaan era digital ini siswa sudah mengetahui banyak tentang internet komputer, e-book.

Jadi materi tentang makam Puyang Ulak Laut dapat dijadikan sember pembelajaran sejarah berbasis digital di SMA Shailendra Palembang, dan materi tentang makam Puyang Ulak Laut dapat dikembangkan dalam proses pembelajaran digital karena materi makam Puyang Ulak Laut merupakan bagian dari sejarah lokal yang harus dikembangkan dan diterapkan kepada sisiwa, agar dapat menambahkan rasa cinta siswa terhadap rasa cintanya kepada daerahnya sendiri.

Pemahaman guru SMA Shailendra Palembang tentang nilai sejarah yang dimiliki makam Puyang Ulak Laut dapat dijadikan materi sumber pembelajaran sejarah berbasis digital di kelas XI pada standar kompetensi 5.2. Mendeskripsikan perkembangan masyarakat kebudayaan dan pemerintahan pada masa Islam di Indonesia serta peninggalannya. Materi pembelajaran: contoh peninggalan-peninggalan sejarah bercorak Islam diberbagai daerah dan struktur makam yang dapat dijadikan sumber belajar. Dengan mempelajari tentang nilai sejarah yang dimiliki makam Puyang Ulak Laut dapat menambah pengetahuan siswa tentang sejarah daerah mereka sendiri sebagai upaya menambah rasa cintannya terhadap daerahnya sendiri bagi siswa.

Untuk mewujudkan hal di atas sebagai contoh, ketika pembelajaran sejarah lokal, mengenai materi tentang makam Puyang Ulak Laut. Pentingnya belajar sejarah lokal tentang makam Puyang Ulak Laut ini di mana dilihat dari perjuangan Puyang Ulak Laut mempertahankan desanya dengan segala pengorbanan dan ketegasannya sehingga mampu melindungi desa Puyang Ulak Laut ini mampu memberikan perubahan pada Desa Pecah Pinggan, dari penjelasan di atas yang dapat dipelajari dari Puyang Ulak Laut ini dia mencintai desanya dengan berusaha untuk melindungi desa. Setiap siswa diberi tugas untuk membuat laporan hasil penelitian mengenai makam Puyang Ulak Laut. Dengan sendirinya siswa akan berusaha mencari materi yang telah ditugaskan dan mencari informasi dengan tugas yang telah diberikan. Setelah tugas yang diberikan kepada siswa namun yang paling penting adalah siswa telah mendapatkan pelajaran kecakapan hidup dan jiwa dapat menambah pengetahuan siswa tentang sejarah lokal dan menambahkan rasa cintanya siswa terhadap daerahnya masingmasinng, setelah tugas selesai siswa diwajibkan mengupload materi yang diperoleh ke e-book setelah materi di upload siswa bisa mempercantik data yang diperoleh dengan background-background menarik sehingga pembaca tertarik untuk membacanya.

Dari kegiatan pembelajaran di atas dapat menguatkan pemahaman seseorang selama ini yang beranggapan bahwa belajar sejarah ini yang dianggap penuh dengan hapalan dan catatan, mengenai hal itu sebenarnya menghapal dan mencatat memang sangat penting dalam belajar sejarah supaya siswa bisa hafal dan paham akan alur dari peristiwa sejarah lengkap dengan nama tokoh dan tahunnya. Namun yang lebih utama adalah untuk mengetahui dan paham tentang sejarah yang baik dan benar. Selain itu juga menggunakan belajar digital berbasisi e-book ini agar bisa menarik perhatian siswa untuk belajar sejarah dan mengurangi efek bosan siswa karena biasanya siswa belajar menggunakan buku cetak atau LKS, dengan demikian menggunakan e-book ini siswa bisa berkreasi dalam menambahkan background-background yang bagus dan video-video yang terdapat dalam buku digital atau e-book dan menambahkan foto-foto tentang makam, agar siswa tidak jenuh dalam belajar. 


\section{SIMPULAN}

Makam Puyang Ulak Laut ini memiliki sejarah penting bagi berdirinya Desa Pecah Pinggan di mana Puyang Ulak Laut ini adalah orang yang pertama kali pembukaan di Desa Pecah Pinggan, dilihat dari perjuangan Puyang Ulak Laut yang mampu menghentikan ombak besar yang akan menenggelamkan laut tengah semenjak kejadian itu Puyang Ulak Laut ini dijuluki oleh masyarakat dengan sebutan pelindung desa karena masyarakat percaya bahwa Puyang Ulak Laut ini mampu melindungi Desa Pecah Pinggan. Batu besar yang digunakan seperti tampak nisan pada makam Puyang Ulak Laut, dilihat dari segi pemakaman yang melambangkan bahwa makam ini sudah memeluk agama Islam dilihat dari segi pemakaman yang sudah kearah kiblat sama halnya dengan makam yang ada pada saat ini

Adapun nilai sejarah yang diambil dari makam Puyang Ulak Laut adalah teradisi ziarah makam yang masih menggunakan sesajen, yang sering dilakukan oleh warga Desa Pecah Pinggan sebagai penghormatan kepada Puyang Ulak Laut sebagai pelindung Desa Pecah Pinggan.

\section{DAFTAR PUSTAKA}

\section{Buku}

Azwar, S. 2016. Metode Penelitian. Yogyakarta: Pustaka Pelajar.

Laksana, R. B. 2013. Pengantar Kebudayaan Sumatera Selatan. Jakarta.

Mulyana, R. 2014. Mengartikulasikan Pendidikan Nilai. Bandung: Alfabeta .

Sugiyono. 2018. Memahami Penelitian Kualitatif. Bandung: Alfabeta.

Sugiyono. 2017. Metode Penelitian Kuantitatif, Kualitatif dan R\&D. Bandung: Alfabeta.

Sugiyono. 2014. Memahami Penelitian Kualitatif. Bandung: Alfabeta.
Suhadi, Machi, H.H. 1994. Makam-makam Wali di Jawa. Proyek Pengembangan Media Kebudayaan.

\section{Jurnal}

Alimin. "Menggali Kearifan Lokal Sumatera Selatan Melalui Pedestrian Jalan Jendral Sudirman". Dalam Seminar Nasional. Mei 2018. 239.

Djono, Isawati, D.A. "Nilai Historis Komplek Makam Sunan Kudus Sebagai Bahan Pengembangan Sumber Belajar Sejarah Lokal". Dalam Jurnal Candi. Volume 15, 2017. 78.

Ni Made, P.S. "Nilai Kearifan Lokal Tradisi Ongah-ongah di Desa Rous Kabupaten OKU Selatan sebagai Sumber Pembelajaran Sejarah di Pasraman Widya Dharma. Volume 6, 2020. 30.

Sugianto. "Modul Virtual Multimedia Flip Book Dasar Teknik Digital". Dalam Fakultas Pendidikan Teknologi dan Kejuruan Universitas Pendidikan Indonesia. Volume IX, 2013. (101-103).

Wahyuni, Y. U \& A, S. (2016). "Efektifitas Penggunaan Media Pembelajaran Flip Book Terhadap Peningkatan Hasil Belajar Siswa Pada Mata Pelajaran Budi Pekerti di SMA Negeri 4 Bandung". Volume 3, 2016. 24.

\section{Internet}

Badan Pusat Statistik. Kabupaten Ogan Komering Ulu Selatan. Dalam http://bps.go.id. Diakses pada Selasa Februari 2020, pukul 14.30 WIB.

\section{Wawancara}

Wawancara Jlimin, 61 tahun, 21 Mei 2021, pukul 11:25 WIB. 


\section{KETENTUAN PENULISAN ARTIKEL JURNAL KALPATARU}

1. Naskah berbahasa Indonesia yang disempurnakan bertemakan kesejarah yang meliputi hasil penelitian sejarah, pengajaran sejarah dan penelitian kebudayaan.

2. Naskah harus asli dan belum pernah dimuat dalam media lain. Naskah dapat berupa hasil penelitian/artikel kajian konseptual yang ditulis oleh perorangan dan atau kelompok.

3. Naskah ditulis dengan cara-cara yang sesuai dengan ketentuan penulisan artikel ilmiah menggunakan bahasa Indonesia yang baku, berupa ketikan, beserta soft file dalam CD-RW atau dengan mengirimkan email pada redaksi jurnal Kalpataru dengan alamat jurnalkalpatarusejarah@gmail.com, spasi tunggal, jenis huruf arial narrow ukuran 12, dengan panjang naskah antara 8-15 halaman pada kertas A4.

4. Artikel hasil penelitian memuat:

JUDUL

Nama Penulis

Abstrak
: XXX (HURUF KAPITAL)

: (disertai jabatan, institusi, dan email)

: (Bahasa Indonesia yang memuat 100-200 kata diikuti kata kunci, dengan jenis huruf arrial narrow dan ukuran huruf 11 serta dicetak miring).

: (memuat latar belakang masalah, tinjauan pustaka secara ringkas, masalah penelitian, dan tujuan penelitian).

B. METODE PENELITIAN

C. HASIL DAN PEMBAHASAN

D. SIMPULAN : (berisi simpulan).

DAFTAR PUSTAKA : (berisi pustaka yang dirujuk dalam uraian naskah).

5. Artikel Kajian Konseptual memuat:
JUDUL
: XXX (HURUF KAPITAL)
Nama Penulis
Abstrak
: (disertai jabatan, institusi, dan email)
: (Bahasa Indonesia yang memuat 100-200 kata diikuti kata kunci, dengan jenis huruf arrial narrow dan ukuran huruf 11 serta dicetak miring.
PENDAHULUAN
: (memuat latar belakang masalah, tinjauan pustaka secara ringkas, masalah penelitian, dan tujuan penelitian).
Sub Judul
: Sesuai dengan kebutuhan (tanpa numbering).
Simpulan
DAFTAR PUSTAKA
: (berisi simpulan dan saran).

6. Referensi sumber dalam teks artikel ditulis dengan menggunakan side note, contoh (Jalaludin, 1991:79); sementara penulisan daftar pustaka disusun dengan ketentuan. Nama pengarang. Tahun terbit. Judul (dicetak miring). Kota terbit: Nama Penerbit. Contoh: Koentjaraningrat. 2010. Manusia dan Kebudayaan di Indonesia. Jakarta: Djambatan. Daftar pustaka hanya memuat pustaka/sumber yang dirujuk dalam uraian dan disusun menurut abjad tanpa nomor urut.

7. Naskah yang dimuat akan disunting kembali oleh redaksi tanpa mengubah isinya.

8. Naskah yang ditolak (tidak bisa dimuat) akan dikirim kembali ke penulis dengan pemberitahuan tertulis dari redaksi atau melalui email.

9. Penulis yang naskahnya dimuat akan mendapat 1 (satu) majalah nomor yang bersangkutan.

10.Kontak person: Muhamad Idris (081271498618); Eva Dina Chairunisa (082281267851); Jeki Sepriady (085269261780). 